\title{
Szinergiacsászárok vagy szauruszok? (A globális légi közlekedés giga-fordító- korongjai a Közel-Keleten)
}

A Perzsa-öböl térsége az Európa és a Távol-Kelet közötti kedvezô logisztikai fekvését kamatoztatva multikontinentális légi közlekedési forgalmi fordítókorong-szerepre berendezkedve (mind a távolsági légi közlekedésben, mind a tengeri áruszállitásban) perifériából a globális közlekedés új súlyponti területévé vált. A gazdasági szerkezet átalakulása és Dubaj légi közlekedési szektorának példátlan növekedésében közrejátszó külső és belső tényezők elemzése, - amelyek révén a versenyképességben globális viszonylatban is a legerósebbek közé tartozik - értékes, újszerü megállapításokhoz vezet.

DOI 10.24228/KTSZ.2017.3.1

\author{
Dr. Erdôsi Ferenc \\ DSc, kutató professor emeritus \\ KRTK Regionális Kutatások Intézete \\ e-mail: erdosi@rkk.hu
}

\section{BEVEZETÉS}

Az Egyesült Államok deregulációs törvénye (1978) világszerte felpörgette a légi közlekedésben a szolgáltatók közötti versenyt, arra késztetve a légitársaságokat, hogy a „ponttól pontig" közlekedés helyett álljanak át a jóval hatékonyabb hub and spoke vonalhálózati rendszerre. E gazdasági késztetésnek megfelelően a nagy amerikai légitársaságok a számításaik szerint legmegfelelőbbnek talált repülötereket gyüjtő/elosztó forgalomra berendezett csomópontokként, azaz forgalmi fordítókorongként használták [6]. Mivel az USA-ban a belföldi forgalom a többszöröse a nemzetközinek, a piacot uraló féltucatnyi óriás társaság elsősorban a belföldi utas- és légiáru-szállitó járatok hálózata számára hozta létre a saját hubját (az American Airlines Dallasban, a Delta Atlantában, a Northwest A. Minneapolisban, a TWA St. Louisban, a United Airlines Houstonban stb. - [7]).
Azonban még a fejlett világban (Európa, ÉszakAmerika, Kelet-Âzsia) is csak néhány jelentös repülötér vált a nemzetközi/interkontinentális forgalom gyüjtö/elosztó csomópontjává, ahol az utasok legalább 30\%-a egy másik járatra átszállva folytatja útját (transzferutasként). Ezek közül kiemelkedik London-Heathrow, Tokió Narita, de ezeken felül a célforgalomhoz képest viszonylag jelentős a transzferforgalma Frankfurtnak, Párizs két nagy repülöterének, Moszkvának, Madridnak is.

A legnagyobb nyugat-európai és kelet-ázsiai hub repülőterek az átszálló/átrakodó hely, illetve közvetítő szerepükön kívül nagy vagy éppen hatalmas népességü országok célforgalmát is hordozzák. A Közel-Keleten belül ez a helyzet Isztambulban is. Ezzel szemben az utóbbi időkben a Perzsa-öböl kis népességü arab országaiban (elsösorban a rendkivül hatékonyan müködö saját légitársaságuknak betudhatóan) néhány repülőtér 


\section{Légi közlekedés}

forgalma elérte a második vonalbeli európai légikikötőkét (évi 10-33 millió utasukkal), és az egyik már a „világrepülőtér” státusnak megfelelőt is. Így ma a Boszporusztól Afganisztánig tartó Közel-Keleten két gigarepülőtér-együttes van kibontakozóban: Isztambulban és Dubajban. Némi időbeli fáziseltolódással ugyan, de mindkét légikikötő globális jelentöségü forgalmi forditókoronggá pozicionálta magát. E szerepkörük folyamatos fejlődésére, a folyamatban levő gigászi méretű infrastruktúra-fejlesztésekre alapozva forgalmuk már középtávon egészen hihetetlen magasságokba (évi 140160 millió utasra) szökik. Ezzel minimum a világ top öt repülötere között foglalhatnak helyet 2020-ban!

\section{A PERZSA-ÖBO̊L MELLETTI OR- SZÁGOK LÉGI KÖZLEKEDÉSÉNEK FEJLÖDÉSE A GAZDASÁGI SZER- KEZET ÁTALAKULÁSÁNAK FŮGG- VÉNYÉBEN}

Egészen az 1960-as évekig a népességszámarányos forgalomban a kiegyenlítettség jellemezte a Perzsa-öböl menti országokat. $\mathrm{Az}$ északi parti Irakban és Iránban a légi közlekedési szektor fejlődése a második világháború után egy ideig még előbbre is tartott a déli partinál (légitársaságok alapítása, működtetése, valamint a repülőtéri infrastruktúra tekintetében). Ugyan az egész öböltérségben már az 1930-1940-es évektől az olajtermelés vált a gazdasági fejlödés motorjává, azonban a formálisan régóta önálló északi parti nagy országok e forrásból már akkor sokat költhettek a nemzeti infrastruktúra-beruházásokra. Erre viszont a brit uralom megszűnése után létrejött déli parti, túlnyomóan apró országokban eleinte csak szolid mértékben volt igény, de lehetőség is.

A szénhidrogén-termelés többszöröződése, az 1970-es évekbeli olajárrobbanás következtében növekvő jövedelmek, majd az iparosítás, a tömeges munkaerő-bevándorlás (és részben az európainál jóval gyorsabb természetes szaporodás) következtében megsokszorozódott és nemzetközi viszonylatban is mobillá vált népesség közlekedési igényei keltettek elöször intenzív célforgalmat. (Részben föként a fejlett világgal - üzleti, kulturális, turisztikai céllal -, de még inkább a vendégmunkások főként dél-ázsiai anyaországaival.) E folyamat következtében a déli parti országok fajlagos légi forgalma 1960 és 2014 között jóval gyorsabban növekedett, mint az iraki és iráni (1. táblázat).

Azonban nem csupán mennyiségi növekedésröl van szó, hanem a forgalom szerkezetében is generális következményekkel járó változás ment végbe. Századunkban már az egyes entitások közötti versengés tétje mindenekelőtt az lett, hogy a többiekhez képest milyen pozíciót képesek elfoglalni az intra-, de még inkább az interkontinentális forgalmi fordítókorong-szerep működtetésében. Hogy e tekintetben egymáshoz képest milyen helyezést tudtak elérni, abban alig volt szerepe a történelmi múltjuknak, a déli parton belüli földrajzi fekvésüknek (viszonylag közel vannak egymáshoz), annál inkább a céltudatos, az „olaj utáni időkre” felkészülő nemzeti gazdaságpolitikáknak. E tekintetben a stratégiák igencsak különböztek, és többnyire az időrendbeli szukcesszió mentén alakultak.

Elöször az importhelyettesitési célú gazdasági struktúraváltás jegyében az élelmiszerbehozatalt mérsékelendő a sivatagi (jobb esetben félsivatagi) területeken fúrt kutakkal öntözéses mezőgazdasági művelésre rendezkedtek be, sőt erdőket telepítettek szárazságtűrő fafajtákkal. (Szaúd-Arábia óriási ráfordítással a belföldi fogyasztást meghaladó mennyiségü búzát termelt egykét évig.) A rétegvízkészletek azonban oly mértékben megcsappantak, hogy a rohamosan növekvő városok vezetékes vízellátása is veszélybe került, ezért a tengervíz (roppant energiaigényes, költséges) sótlanításával lehetett édesvizet elöállítani. (E megoldásra először Kuvait kényszerült, majd a többi sivatagi országban is elterjedt: naponta akár egy-másfél millió $\mathrm{m}^{3}$ édesvizet előállító parti deszalinációs berendezések épültek, amelyekből csővezetéken juttatják el a vizet a távolabbi városokba is.) 
1. táblázat: A Közel-kelet országai népességének és repuilőtéri utasforgalmának adatai

\begin{tabular}{|c|c|c|c|c|c|c|}
\hline \multirow[t]{2}{*}{ Ország } & \multicolumn{2}{|c|}{$\begin{array}{l}\text { Népességszám, } \\
\text { millió fö }\end{array}$} & \multirow{2}{*}{$\begin{array}{l}\text { Növekedési } \\
\text { index, } \\
1960=100\end{array}$} & \multicolumn{2}{|c|}{$\begin{array}{c}\text { Az egy lakosra jutó } \\
\text { utasszám, fö }\end{array}$} & \multirow{2}{*}{$\begin{array}{l}\text { Növekedési } \\
\text { index } \\
1960=100\end{array}$} \\
\hline & 1960 & 2014 & & 1960 & 2014 & \\
\hline Törökország & 27,8 & 80,1 & 288,1 & 0,181 & 1,990 & 1100 \\
\hline Irán & 20,6 & 79,0 & 383,5 & 0,059 & 0,570 & 961 \\
\hline Szaúd-Arábia & 6,5 & 31,0 & 476,9 & 0,224 & 1,980 & 884 \\
\hline Irak & 6,7 & 34,0 & 507,5 & 0,016 & 0,080 & 473 \\
\hline Jemen & 5,2 & 25,9 & 498,1 & 0,006 & 0,090 & 1430 \\
\hline Szíria & 4,2 & 20,0 & 476,2 & 0,050 & 0,210 & 423 \\
\hline Izrael & 2,1 & 8,5 & 404,8 & 0,112 & 2,030 & 1814 \\
\hline Jordánia & 1,5 & 6,8 & 453,3 & 0,095 & 0,880 & 923 \\
\hline Libanon & 1,6 & 5,0 & 312,6 & 0,270 & 1,470 & 544 \\
\hline Omán & 0,61 & 4,2 & 688,5 & 0,118 & 2,280 & 1987 \\
\hline Egyesült Arab Emírségek & 0,45 & $4,5^{*}$ & 1000,0 & 0,704 & 13,010 & 1849 \\
\hline Kuvait & 0,22 & 3,6 & 1636,4 & 0,147 & 2,930 & 1988 \\
\hline Katar & 0,04 & 2,3 & 5750,0 & 0,824 & 10,680 & 1296 \\
\hline Bahrein & 0,15 & 1,2 & 800,0 & 0,616 & 6,830 & 1107 \\
\hline Összesen & 77,67 & 306,1 & 393,9 & 0,129 & $1,530 * *$ & 1189 \\
\hline
\end{tabular}

* A vendégmunkaerővel és családtagjaikkal együtt becslések szerint 8,6 millió fő; a többi országban feltehetően a bevándoroltakkal együtt számított lakónépességről van szó

** súlyozott számtani átlag

Forrás: UN Statistical Yearbook 1960-2014 és ICAO Statistics Yearbook alapadatai, valamint a szerző által számított viszonyszámok.

Miután az agrárfejlesztések a környezeti korlátok miatt csődöt mondtak, valamennyi olaj- és gáztermelő ország szénhidrogén-vegyészeti, valamint más feldolgozóipart telepített, amelyek termékeit föként belföldi használatra állították elő (üzemanyagok, kenőolajak, építőanyagok, üveg, kerámia, alumínium- és acélszerkezetek stb.), de újabban exportra is termelnek (alumínium, vegyipari, gépipari termékeket stb.).

A szerkezetváltás azonban nem állt meg az iparosításnál, hanem egyre inkább a magasabb hozzáadott értéket elóállitó tevékenységek felé nyitott. Ezek közé tartozott a távoli régiók közötti cserekereskedelem/árudisztribúció új dimenziókban felfejlesztése. Amíg a gépi hajózás előtti időkben a Perzsa-öböl/Arab-félsziget gyér lakossága (a nomád állattenyésztésen, a tengeri halászaton, kagylógyüjtésen kívül) a max. néhány tonna hordképességü vitorlás hajókkal Perzsia, India, Perzsa-öböl és Kelet-Afrika között kis tételekben, ám nagy értékü árukkal folytatott cserekereskedelmet, ma már jobbára a távol-keleti (főként kínai) ömlesztett iparcikkek megfelelő csomagolás utáni nemzetközi közvetítő kereskedelmével, sőt az áru mozgatását feleslegessé tevő börzén történő értékesítésével foglalkoznak az európai, afrikai, közép-ázsiai vevők számára. A bevételek további jelentős része a drágakő- és nemesfém-, illetve ékszerkereskedelemből származik.

Még nagyobb előrelépést jelentett a szerkezetváltásban a több kontinensre kiterjedő banki és biztosítási ügyletek felvállalása, legújabban pedig a szofisztikus online szolgáltatások teljesítése távmunkával transznacionális cégek és más megbízók számára.

A gazdasági szerkezetváltás folyamatosan növelte az öböl menti országok légi célforgalmát, de ezzel nem érték be, hanem nemzetközi csomópontszerepre is törekedtek [11].

\subsection{Küzdelem a nemzetko̊zi légi közleke- dési fordítókorong-szerepért}

Hatalmas gazdasági és logisztikai potenciállal rendelkezik a Közel-Kelet a földrajzi fekvéséből, azaz abból az adottságából, hogy köztes, illetve átmeneti helyzetet élvez a globális gazdaság két erőközpontja, Európa és (Kelet-) Ázsia között.

A 20. század derekáig a korlátozott hatótávolságú repülőgépek a transzkontinentális és földrészek közötti nagy távolságú viszonylatokban kénytelenek voltak köztes müszaki megállókon 


\section{Légi közlekedés}

megszakítani útjukat. (Így pl. Európa és Afrika déli része között Kano, Európa és Dél-Amerika között Dakar, Észak- és Dél-Amerika között föként Panamaváros repülöterén tankoltak a gépek.) A Perzsa-öböl térségében üzemanyagfeltöltő helyként több repülötér is bekapcsolódott a transzeurázsiai (és Európa-Ausztrália viszonylatú) forgalomba. Közöttük már az 1930/1950-es években versengés alakult ki a forgalom növelése érdekében. Azoknak állt igazán a zászló, amelyek a legtekintélyesebb európai légitársaságok (British Airways, KLM, Lufthansa) járatait voltak képesek kiszolgálni.

Ugyan a 6-10 ezer km-es, nagytávolságú (Európa-Távol-Kelet) járatok köztes leszállóhelyei már korán lehetővé tették, hogy a tágabb térségükböl néhányszáz km-es ráhordó (feeder) járatokat üzemeltessenek kis helyi társaságok, az együttmüködésre alapozott transzferforgalom egy ideig szerény volt. E helyzeten gyökeresen változtatott a deregulációs/liberalizációs közlekedéspolitika és az olajárak drasztikus emelkedése az 1970-es években. A légitársaságok a verseny során úgy igyekeztek a repülőjegyek árát csökkenteni, hogy járataikon a lehető legalacsonyabbra szorították az üzemanyag tömegét a repülőgép teljes súlyából, azaz a lehető legmagasabb arányú nettó „fizetö” (produktív) súlyarányra törekedtek. A sugárhajtómüves gépek széles körü alkalmazása ugyan az 1960-as évektől lehetővé tette az Európa-KeletÁzsia/Kelet-Afrika viszonylatokban is a közvetlen járatok közlekedtetését, ám a gépek bruttó tömegének akár a 30\%-át is elérő betankolt kerozin (mint „improduktív” szállítmány) hordozásának költségterhével. Ezért a közvetlen járatok utasai magasabb árat fizettek. Ezzel szemben, ha az adott távolsági géptípus megszakíthatja útját 3000$4000 \mathrm{~km}$ megtétele után, úgy csak „féltanknyi” kerozint betankolva több utast képes szállítani (az ülések számának növelésével), és a poggyásztér kereskedelmi áruval való teljes kihasználásának sincs akadálya. Még nagyobb lehetőség adódik a nettó szállítmány növelésére a teheráru-szállító (cargo) repülöjáratoknál. Ilyen módon csökkenthető a személy- és a kereskedelmi áruk fajlagos szállítási költsége, végső soron pedig a szolgáltatási dijtétele is [18]. De ennél még nagyobb előny származik abból, hogy az útmegszakító repülötéren lehetőség kínálkozik a nagyarányú utascserére, a több irányban való továbbutazásra, illetve a több irányból érkező utasok (és áruk) továbbszállítására a járat célrepülőteréig.

E költségcsökkentő járatrendszer-szervezés ugyan, elvileg más nagy távolságú viszonylatokban is számításba jöhet, azonban gyakorlatilag igazán a két nagy gazdasági tömörülés (Európa és KeletÁzsia) között érvényesíthető, mivel itt túlnyomóan szárazföld felett vezet az út, ahol vannak repülőterek. (Ellentétben az óceánok feletti interkontinentális viszonylatokkal, ahol útmegszakításra nincs lehetőség.) Ez az adottság kiválóan érvényesül a Közel-Keleten, amit jól jelez, hogy a repülötéri transzferutasok részaránya valamennyi világrész közül itt a kiugróan legmagasabb, eléri a $12 \%$-ot, míg a második helyen álló Európában nem több 3,8\%-nál (2. táblázat). A fő kérdés itt az, hogy a fordítókorong-funkcióért folytatott versenyben mely országok (illetve tartományok) repülöterei képesek vezető szerepre szert tenni.

\begin{tabular}{|c|c|c|c|c|}
\hline Világrész & Csomópontok & $\begin{array}{l}\text { Átszálló utasok } \\
\text { száma, } \\
\text { fö }\end{array}$ & $\begin{array}{c}\text { Növekedés, } \\
\text { 2009-2013, } \\
\%\end{array}$ & $\begin{array}{c}\text { Transzferutas } \\
\text { az összes utas } \\
\text { \%-ában }\end{array}$ \\
\hline Ázsia & $\begin{array}{l}\text { Sanghaj, Hongkong, Peking, Tokió, } \\
\text { Szingapúr, Szöul }\end{array}$ & 24797116 & 20,1 & 2,0 \\
\hline Európa & $\begin{array}{l}\text { Frankfurt, Párizs (CDG), London (Heath- } \\
\text { row), Amszterdam, Madrid, Isztambul }\end{array}$ & 39915881 & 10,0 & 3,8 \\
\hline Dél- és Közép-Amerika & $\begin{array}{l}\text { Mexikóváros, Bogota, Lima, Sao Paulo, } \\
\text { Buenes Aires, Caracas }\end{array}$ & 6570340 & 57,0 & 3,0 \\
\hline Közel-Kelet ${ }^{*}$ & Dubaj, Abu-Dzsabi, Doha & 19228052 & 78,6 & $12,0^{*}$ \\
\hline Észak-Amerika & $\begin{array}{l}\text { Atlanta, New York, Orlando, Chicago, Los } \\
\text { Angeles, Miami }\end{array}$ & 17209541 & 7,7 & 1,4 \\
\hline
\end{tabular}

* Nem tartalmazza Törökországot.

Forrás: Eredeti Oxford Economics Amadeus..., közli Batchelor 2014, kiegészítve a szerző számításaival. 
A Perzsa-öböl országai közül az északi parti Irán és Irak legnagyobb repülőtereinek (Bagdad, Teherán) elhanyagolható a nemzetközi transzferforgalma. A déli parti „olajországok” közül Kuvait sem törekszik érdemleges csomópontszerepre: légitársasága (Kuwait Airlines) repülőgépparkjának nagyobb részét csak közepes hatósugarú gépek alkotják, amelyek az intraregionális célforgalom hordozói. Kuvait város repülöterén a transzferutasok aránya nem éri el az 5\%-ot. Szaúd-Arábia az erősen decentralizált területi struktúrájára is visszavezethetően úgyszintén beéri a régión belüli szolidabb mértékü transzferrel, közlekedési stratégiájában sem zászlós légitársaságának, sem három nagy légikikötöjének (Dzsidda, Rijád, Damman) nem szánt jelentősebb szerepet a transz- és interkontinentális léptékü közvetítő forgalomban. Bahrein ugyan egykor az egész régió légi irányításának központja (sőt rövid ideig a Concorde járatok egyetlen közel-keleti célrepülőtere) volt, azonban a miniországnak eleve sem a légitársasága (Gulf Air) sem az egyetlen nemzetközi repülőtere (Manana) nem szállhatott be eséllyel a szemiglobális jelentőségü nemzetközi hubért folytatott versenybe [16]. Mindössze három entitás (Katar, az egyesült arab emírségi Abu-Dzabi és Dubaj) híres légitársasága (Qatar Airways, Etihad, Emirates), illetve nagy nemzetközi repülőtere (Doha, Abu-Dzabi, Dubai International/Al Maktoum komplexum) maradt a „ringben”. Közöttük a győzelmet - hasonló ambíciók mellett - alapvetően a fejlesztésekbeli céltudatosság, összpontosítás, sőt a túlzás nélkül agresszívnek minősíthető piacszerzés döntötte el. Mindezeknek a tulajdonságoknak a legkifejezettebben (az Egyesült Arab Emírségeken belüli) Dubaj Emírség légi szektora volt a birtokában. Ezekhez zárkózott fel a rendkívül magas technológiai és szervezési szintü nemzetközi (globális léptékü) légi közlekedés és a tengeri konténeres szállítás magas transshipment (átszállás/átrakás) arányával. A 2010-es években a légi közlekedési szektor Dubaj GDP-jének már közel az egyharmadát állította elő. (Ehhez fogható magas részaránnyal csupán Izland dicsekedhet.)

\subsubsection{Miért éppen Dubaj?}

Alig létezik olyan, akár csak újságot olvasó, tv-t néző ember, aki ne tudna arról, hogy Dubaj milyen gazdag, milyen hihetetlenül látványos, hogy rekordmagasságú és -méretű épületekkel, bevásárló- és szórakoztatóközpontokkal, fantasztikus infrastruktúrával rendelkezik. „Könnyü nekik, az olajból mindent megtehetnek" - nagyjából ez a sztereotip vélekedés, ami azonban alig van köszönőviszonyban a mai valósággal. Egyelőre elégedjünk meg azzal a témánk szempontjából fontos információval, hogy a teljes olaj- és gázszektor ma csupán 6-8\%-kal járul hozzá az emírség GDP-jéhez. Úgy gondoljuk, hogy akár „dubajosodás”-nak is nevezhetjük a világ kisebb államaiban/entitásaiban tapasztalt feltünően gyors és magas átlagos jövedelemhez vezető gazdasági fejlődést [9]. E tekintetben Dubaj modellnek tekinthető [13]. Mivel Dubaj a többi emírséghez képest korábban is szerényebb szénhidrogénkészletekkel rendelkezett, késztetve volt az olajbevételeit a lehető leghatékonyabban, magasabb hozzáadott értéket előállító kutatás-fejlesztési, információ-technológiai, IT szektorokban kamatoztatni.

Az emírség gazdasági versenyképességének, tőkevonzó erejének számos összetevője van, úm.:

- minimális a kormány általi ellenőrzés, beavatkozás, nincs jövedelemadó (a külföldi bankok és az olajtársaságok kivételével), a vámilleték csekély (4\%);

- alacsonyak az energiaköltségek;

- versenyképesek a munkaköltségek (külföldi és soknyelvü, részben Dubajban képzett munkaerő áll rendelkezésre);

- magas életminőség, kiváló életfeltételek, egészségügyi és oktatási szolgáltatások teszik vonzóvá [18].

Az anyagiakon kívül a különböző szellemi attribútumok cseréje is már évtizedek óta folyik az EAE legsikeresebb emírségében: az egész világra kiterjedő tevékenységet folytató financiális intézményóriások mozgatják a milliárd dollárnyi E-pénzeket, kutatóintézetek és I+K cégek az információkat. A City Mayors a globális pénzvilág egyik nemzetközi pénzügyi központjának tekintette Dubajt.

Észak-Amerika és Izrael után a legtöbb esetben Dubajban kerülnek elöször alkalmazásra a legújabb infokommunikációs, egészségügyi és oktatási technológiák, a frissen megjelenő legkülönbözőbb szofisztikált innovációk. A helyi infrastruktúrák sorából jelentőségben kiemelkedik a Dubai Internet City. Ez a Dubai Media Cityvel együtt egy professzionális komplexum, amely olyan nevezetes IT és más technológiai társaságokat foglal magában, 


\section{Légi közlekedés}

mint az Oracle Co., Microsoft, IBM és EMC Co., továbbá globális szinten jelenlevő médiacégeket: Reuter, AP CNN, BBC, MBC és Sky News [5]. Az infokommunikációs és kulturális fejlesztések egyben a nagy volumenűvé vált turizmust is szolgálják. Az egy lakosra jutó külföldi látogatók száma tekintetében Dubaj az elsők közé tartozik a világon.

Mindezek az előnyök abban is megjelennek, hogy Dubaj számos regionális vezető testület, szervezet központja, nemzetközi találkozók, konferenciák, világkiállítások, rendezvények színhelye. E tevékenységek magas haszonkulcscsal müködnek, és közvetett hatásuk az emírség anyagi kondícióira több mint jótékony.

Az öbölbeli légitársaságok számára jól jön, hogy az európaiak a nagytávolságú viszonylatok közül a legnagyobb hasznot hozó észak-atlanti piacra orientálódnak. Így az európaiakat könnyebb kiszorítani a transzeurázsiai piacról az „open sky” jegyében és a 6. légi közlekedési szabadságjog alapján. (Azaz „A”-ból „B” országba az utas/ áruszállítás a repülőgép anyaországában történő járatcserével megy végbe [22]).

A liberalizáció/dereguláció előrehaladtával egyre engedékenyebb nemzetközi szabályozási keretek adta lehetőséggel élve a kivívott engedményeknek nem kevés része volt abban, hogy a legnagyobb három öbölbeli légitársaság, azaz az Egyesült Arab Emírségek és Katar világhírü nagy légitársaságai (a továbbiakban 3NT) együttesen képesek voltak a távolsági közlekedésben 2003 és 2009 között a kapacitásukat valamivel gyorsabban növelni, mint a nagy európai, délkelet-ázsiai és ausztrál légitársaságok (3. táblázat).

\begin{tabular}{l|c|c|c|}
\hline & \multirow{3}{*}{$\begin{array}{l}\text { 3. táblázat: Nyolc nagy légitársaság nemretközi } \\
\text { Lonalainak száma }\end{array}$} & $\begin{array}{c}\text { Légi vonalak } \\
\text { száma } \\
\text { összesen } \\
2009-b e n\end{array}$ & Ebből 2003 óta létrehozottak \\
\cline { 3 - 4 } & 159 & 89 & $\%$ \\
\hline Lufthansa & 155 & 43 & 27,7 \\
\hline Air France & 106 & 69 & 65,1 \\
\hline British Airways & 99 & 41 & 51,7 \\
\hline Emirates & 79 & 45 & 57,0 \\
\hline Qatar Airways & 60 & 31 & 51,7 \\
\hline $\begin{array}{l}\text { Singapore } \\
\text { Airlines }\end{array}$ & 59 & 59 & 100,0 \\
\hline Etihad Airways & 42 & 36 & 85,7 \\
\hline Qantas Airways & &
\end{tabular}

Forrás: OAG 2010, közli Murel-O'Connell 2011; szerzö által kivonatolva és viszonyszámokkal kiegészitve.
A 3NT a saját hub repülőterén keresztül közlekedtetett járatainak aránya tekintetében Doha vezet:

- Emirates (Dubajon keresztül) 50\%-ot,

- Etihad Airways (Abu-Dzabin keresztül) 70\%-ot,

- Qatar Airways (Dohán keresztül) 80\%-ot ért el (Flug Revue 2008).

Az öbölbeli légitársaságok valamilyen módon állami támogatásban részesülnek, még ha ezt kevesen ismerik is el. E pótlólagos forrás birtokában lehetőségük van olyan mértékü beruházásokra, amilyenekről az európai szolgáltatók még csak nem is álmodhatnak.

\subsubsection{A dubaji nemzeti zászlós légitársaság, az Emirates eddigi utolérhetetlensége a haté- konyságban}

Az EAE, sőt a Közel-Kelet legnagyobb légitársasága az Emirates, amely globális szinten a bevétel tekintetében a 7., a nemzetközi utasforgalomban a 4., a menetrendszerü utaskilométer alapján a 3. legnagyobb légitársaság. A világ 5. legnyereségesebben müködő légitársasága egyebek mellett $80 \%$-os ülőhely-kihasználást ért el.

Dubaj nemzeti légitársaságának páratlan sikerét számos hatótényező kedvező alakulásának, szinergikus hatásainak köszönheti. Ezek részben nemzetközi, részben országos (EAE) szintüek, de nem utolsó sorban a sejkségen belüli helyi tényezők, adottságok és folyamatok.

A külső tényezők szerepével kapcsolatosan az igazi kérdés az, hogy a 3NT közötti verseny eddig hogyan alakult. Az ezekkel kapcsolatos elemzéseinkből arra a megállapításra juthatunk, hogy az Emirates számára a többi öbölbeli arab légitársaság eddig nem lehetett igazi versenytárs, mert

- jóval későbbi alapításúak, amikorra a dubaji légitársaság már régen megvetette a lábát a piacon, és ezért vele szemben a többiek nehezen tudtak teret nyerni;

- a potenciális versenytársak flottája, földi infrastruktúrája, bázis-repülőterének kapacitása méreteiben mindmáig jóval kisebb, a nagytávolságú viszonylatokban nem versenyképes (4. táblázat). 
4. táblázat: Az öbölbeli vezető légitársaságok és hub repuilőtereik főbb forgalmi adatai

\begin{tabular}{|c|c|c|c|c|c|c|c|c|c|c|c|c|}
\hline Alapítás éve & \multicolumn{2}{|c|}{1985} & \multicolumn{2}{|c|}{1993} & \multicolumn{2}{|c|}{$1950 / 1974$} & \multicolumn{2}{|c|}{2003} & \multicolumn{2}{|c|}{$1993 / 1970$} & \multicolumn{2}{|c|}{1954} \\
\hline \multirow{2}{*}{$\begin{array}{l}\text { Jellemzők/mu- } \\
\text { tatók }\end{array}$} & \multicolumn{2}{|c|}{ Emirates } & \multicolumn{2}{|c|}{ Qatar A. } & \multicolumn{2}{|c|}{ Gulf Air } & \multicolumn{2}{|c|}{ Etihad } & \multicolumn{2}{|c|}{ Oman Air } & \multicolumn{2}{|c|}{ Kuwait A. } \\
\hline & 2006 & 2015 & 2006 & 2015 & 2006 & 2015 & 2006 & 2015 & 2006 & 2015 & 2006 & 2015 \\
\hline $\begin{array}{l}\text { a) Légitársaságok } \\
\text { forgalma, M utas }\end{array}$ & 14,5 & 40,8 & 6,0 & 19,1 & 7,0 & 8,9 & 2,9 & 10,3 & 3,8 & 6,0 & 6,1 & 10,6 \\
\hline $\begin{array}{l}\text { b) Hub repülö- } \\
\text { terek }\end{array}$ & \multicolumn{2}{|c|}{ Dubaj } & \multicolumn{2}{|c|}{ Doha } & \multicolumn{2}{|c|}{ Bahrein } & \multicolumn{2}{|c|}{ Abu-Dzabi } & \multicolumn{2}{|c|}{ Muszkat } & \multicolumn{2}{|c|}{ Kuvait } \\
\hline $\begin{array}{l}\text { c) A társaságok } \\
\text { repülőgépeinek } \\
\text { száma }\end{array}$ & 99 & 235 & 53 & 158 & 34 & 28 & 20 & 116 & 40 & 45 & 14 & 23 \\
\hline \multicolumn{13}{|l|}{ ebből } \\
\hline - távolsági & 95 & 230 & 27 & 109 & 15 & 6 & 19 & 81 & 12 & 30 & 4 & 13 \\
\hline - rövid járatú & 4 & 5 & 26 & 49 & 19 & 22 & 1 & 35 & 28 & 27 & 10 & 10 \\
\hline $\begin{array}{l}\text { d) A társaságok } \\
\text { destinációinak } \\
\text { száma/ország }\end{array}$ & $124 / 55$ & $160 / 70$ & $117 / 57$ & $146 / 78$ & $34 / 13$ & $143 / 23$ & $24 / 10$ & $116 / 59$ & $31 / 18$ & $50 / 27$ & $28 / 15$ & $34 / 23$ \\
\hline $\begin{array}{l}\text { e) A társaságok } \\
\text { alkalmazottainak } \\
\text { száma, ezer fö }\end{array}$ & 26 & 50 & 10 & 21 & 9 & 10 & 13 & 20 & 3 & 6 & 5 & 11 \\
\hline $\begin{array}{l}\text { f) A hub repülőtér } \\
\text { forgalma, M utas }\end{array}$ & 28,9 & 78,5 & 16,2 & 32,8 & 6,1 & 8,6 & 13,6 & 31,2 & 4,0 & 9,0 & 6,9 & 11,1 \\
\hline $\begin{array}{l}\text { g) A reptérről el- } \\
\text { érhető destinációk } \\
\text { száma }\end{array}$ & $204 / 132$ & $270 / 148$ & $198 / 87$ & $248 / 112$ & $39 / 17$ & $53 / 24$ & $71 / 48$ & $96 / 55$ & $30 / 16$ & $42 / 19$ & $39 / 21$ & $59 / 34$ \\
\hline
\end{tabular}

Forrás: Légitársaságok és repülőterek honlapjainak adataiból szerkesztette a szerző

Az Emirates sikerességében a belső tényezöknek (a gazdasági adottságoknak és az emírség sajátos társadalmi struktúrájának) legalább akkora szerep tulajdonitható, mint a külsőknek.

Az emírségbeli gazdasági környezetböl adódik, hogy a társasági szintü üzemi költségek közül a legnagyobb előny az európaihoz képest jóval alacsonyabb (a németországinál 48\%-kal, a svájcinál 58\%-kal kisebb) személyi költségekből származik. Az alacsony költségek részben az olcsó bérü vendégmunkaerő foglalkoztatásának, részben a szociális biztosítási rendszer csaknem teljes hiányának tulajdoníthatók. (A fizikai munkát végzőknek és a kishivatalnokoknak nincs egészségügyi/balesetbiztosítása, a társaság vagy az emírség által fizetett családi pótlékra nem jogosultak, sőt gyakorlatilag kénytelenek lemondani az üzemi tanácsok, szakszervezetek létrehozásáról is.)

Az olcsó munkaerőn kívül a siker másik öszszetevője a flotta kor-és újszerüsége. 2014 márciusában a repülőgép-állomány átlagos életkora 6,3 év volt. Ennek köszönhetően az üzemanyagköltségek terén Dubaj mintegy 20\%-kal kedvezőbb helyzetet élvez az európai légitársaságok átlagához képest, annak ellenére, hogy a kerozin árában nincs semmiféle állami támogatás.

A dubaji társaság a legtekintélyesebb nyugat-európai British Airways-szel és a délkelet-ázsiai Singapore A.-nal szemben a legtöbb költségnem tekintetében kedvezőbb helyzetben van (5. táblázat).

A repülögépek beszerzési költségei tekintetében is némi előny adódik abból, hogy az Emirátus egyszerre és ugyanabból a típusból meglehetősen nagy számú gépet rendel meg, és lehetőleg olyan időpontban, amikor a gyártók a hirtelen csökkenő megrendelések miatt hajlandók árengedményt adni. (Mint pl. 2001. szeptember 11 után vagy éppen a gazdasági válság alatt.)

A légitársaságok járatainak üzemeltetése során felmerülő külső költségek közül az utasok után az Emirates Dubaj repülőterén 78\%-kal kevesebb illetéket fizet, mint Frankfurtban! A külföldi repülőtereken történő valamennyi fizetési kötele- 


\section{Légi közlekedés}

5. táblázat: Az Emirates, a British Airways és a Singapore költségszerkezete 2008-ban, USD

\begin{tabular}{|l|c|c|c|c|c|}
\hline Költségfajta & Emirates & British Airways & $\begin{array}{c}\text { Singapore } \\
\text { Airways }\end{array}$ & E/BA & E/SI \\
\hline Üzemanyag/tkm & 8,12 & 11,40 & 9,71 & -29 & -16 \\
\hline Személyi költség/tkm & 4,30 & 12,01 & 5,89 & -64 & -26 \\
\hline Leszállási és irányítási/tkm & 1,45 & 2,93 & 1,28 & -51 & -13 \\
\hline Kezelési/tkm & 1,69 & 5,42 & 1,13 & -69 & -50 \\
\hline $\begin{array}{l}\text { Repülögép karbantartás/ } \\
\text { tkm }\end{array}$ & 0,50 & 2,50 & 0,83 & -80 & -40 \\
\hline Amortizáció/tkm & 1,34 & 3,84 & 2,96 & -65 & +109 \\
\hline $\begin{array}{l}\text { Értékesítési disztribúció/ } \\
\text { tkm }\end{array}$ & 2,80 & 1,99 & 1,34 & & +41 \\
\hline Üzemelési bérlet/tkm & 2,83 & 0,38 & 0,74 & +645 & +282 \\
\hline A költségek összesen/tkm & 26,56 & 43,69 & 26,75 & -39 & $-0,7$ \\
\hline A bevételek összesen/tkm & 28,78 & 45,55 & 30,86 & -41 & $-6,7$ \\
\hline
\end{tabular}

* tkm tartalmazza az összes szállítmány (utas, légi áru, poggyász, postai küldemény) teljes súlyát a megtett kilométerek számával szorozva

E/BA - az Emirates és a BA költsége közötti különbség, \%

E/SI - az Emirates és a Singapore A. költsége közötti különbség, \%

Forrás: Muro-O’Connell 2011.

zettség alapján az Emirates teljes hálózatának müködtetésére vonatkoztatott külső szolgáltatások ellentételezése és a többféle illeték fizetése 39\%-kal marad el az Európában szokásostól.

A repülőgépfüggö üzemelési költségek Dubajban elsősorban azért lehetnek alacsonyabbak, mert nem szednek zajvédelmi és emissziós dijakat, mint ahogyan parkolási dijakat sem. (Fizetésre csak akkor kerül sor, ha a repülőgép tartózkodási ideje a repülötéren eléri a hat órát.) A nélkülözhetetlen navigációs szolgáltatásokat Dubajban 0,31 euró/ utas árért lehet elérni, a frankfurti 1,66 és a zürichi 2,84 euró/utas költséggel szemben, ahol alig van szabad résidő újabb járatok fogadásához [18].

Az Emirates menedzsmentjének kiváló üzleti érzéke volt ahhoz, hogy a légitársaság a legjobban jövedelmezö, kizárólag nagytávolsági járatokkal gyakorolt világrészek közötti közvetítö szerepkörre szakosodott, lemondva a fajlagosan jóval költségesebben üzemelő rövid feeder járatok üzemeltetéséről. Ezzel a profiltisztítással a dubaji zászlós társaság mintegy 20\%-os költségmegtakarítást élvez a vegyes funkciójú nyugat-európai nagy társaságokhoz képest.

A sajátos társadalmi struktúrákból származóak azok a müködési elönyök, hogy az Emirates $100 \%$-ig állami tulajdonban van és az egyes részlegeit a Dubaj Emírség uralkodójának né- pes családja birtokolja. Ez az európai szempontból meglehetősen idegennek tünő struktúra meglepően hatékony. A rokonok közötti szakmai egyeztetések kétségtelenül elősegítik az üzemelés hatékonyságát, a problémáknak a nyugati demokráciákban megszokottnál jóval rövidebb időn belüli megoldását. Jelentős szinergia származik abból is, hogy a légitársaság és a hub repülötér azonos tulajdonban van. A közös tulajdonos képes a kétféle tevékenységet harmonizálni, a beruházásokat a tényleges forgalmi igényekre méretezni.

Valamennyi előbbi rész-hatótényezőt mérlegelve a szakértők arra a következtetésre jutottak, hogy Dubaj légi közlekedési szektorának teljes körü költségelönye a nyugat-európaihoz képest 30\% körüli lehet [18]. Az Emirates a 2008. évi világgazdasági válságot is veszteség nélkül sikeresen túlélte, és nem csupán az európai, valamint amerikai versenytársaival szemben állja a sarat a kedvezőtlen világgazdasági helyzetben, hanem még Ausztráliában is érezteti üzleti erejét [15].

\subsubsection{Az Emirates szerepe a kontinensek kö- zötti légiforgalmi kapcsolat megteremtésé- ben a dubaji hubján keresztül}

Bár a kontinensek között (Európa-Távol-Kelet, Ázsia-Észak-Amerika, Közel-Kelet-Latin- 
Amerika) továbbra is számos közvetlen légi járat áll az utazóközönség rendelkezésére (az A380-as alkalmazásával leszállás nélkül akár 15 ezer $\mathrm{km}$ is megtehetö), az Emirates dubaji átszállással mégis meglepően intenzív forgalomra tett szert elsősorban a szolgáltatásainak minősége és a menetjegyárai közötti, az utasok által vonzónak talált viszony okán.

Az Emirates a 2004-2009. évi idöszakban forgalmát - legnagyobb mértékben keletre orientálódva - a világ két legnagyobb országának piacán növelte: kínai viszonylatban 444\%kal, indiai viszonylatban $238 \%$-kal, de még az ausztráliai forgalmat is megkettőzte [4]. Dubaji átszállással az Egyesült Királyság és India között évente átlagosan 2 millióan utaznak, és a Mumbai-New York viszonylatban 5\%-kal olcsóbb menetjegyet kínál az Emirates, mint a Lufthansa. Az Ausztráliába tartó, vagy onnét érkező utasok 75\%-a dubaji átszállással utazik tovább Európába [17]. Mi több, az Afrika és a világ többi része közötti légi forgalom egy részét is sikerült a dubaji fordítókorongra terelni. (Számos afrikai légitársaságot kitiltottak az Európai Unió repülőtereiről mivel nem teljesítették a biztonsági előírásokat. Ezért alkalom nyílott az Emiratesnek, hogy interkontinentális járatváltó konstrukcióval kiszolgáljon 14 afrikai célrepülőteret.)

Ezenközben az Emirates megszerezte Afrika legnépesebb országa, Nigéria-Kína viszonylatú forgalom 20\%-át, továbbá a Nigéria és India közötti 40\%-át (O’Connell 2011).

\section{KEZELHETÖ KONFLIKTUSOK A NYUGATI RIVÁLIS LÉGITÁRSA- SÁGOKKAL, LÉGI EGYEZMÉNYEK A HATÉKONY EGYÜTTMÜKÖDÉSRE}

Az Emirates a mérsékeltebb áraival és a magasabb szintű szolgáltatásaival vált veszedelmes versenytársává az európai és amerikai légitársaságoknak, amelyek azzal a nem teljesen alaptalan váddal próbálják diszkreditálni az EAE zászlós társaságát, hogy az burkolt állami támogatásban részesül [1].

Prémiumkategóriás szolgáltatásait az Emirates ugyan csak a metropoliszok közötti járatain nyújtja, de a világhálózatának többi eleme is kellően vonzó volt ahhoz, hogy olyan földrajzi pontokra is kiterjessze piacát, amelyeket a nagy nyugati társaságok elhanyagoltak (föként a harmadik vonalbeli európai célállomásokra, pl. Hamburgra, Barcelonára, Nizzára bejutva). Pontosan e lépésben érzékelnek veszélyt az európaiak, mert miután a közel-keleti interkontinentális fordítókoronghoz kapcsolódnak, kikerülnek a hagyományos európai csomópontok vonzásából, vagy éppen miután azok vonzáskörébe soha be sem kerültek, erre a jövőben sem lesz lehetőségük.

Az Emirates nyomulása a nyugati piacokon konfliktusokhoz vezetett azzal, hogy ott nem korrektnek ítélt követelésekkel állt elö. Ezért a Lufthansa folyamatosan lobbizott a német kormánynál, hogy korlátozza az Emirates jelenlétét Németországban, konkrétan ne engedélyezze az Emirates Berlinbe és Stuttgartba tervezett járatainak üzemelését.

A Lufthansa önös érdekeivel szemben viszont a két nagyváros (és tartományuk) elfogadhatatlannak tartották a közvetlen kapcsolat hiányát a Perzsa-öböl metropoliszaival. Arra hivatkoztak, hogy miután Dubajjal nem csupán a diplomáciai, államközi kulturális és oktatásügyi, hanem a gazdasági kapcsolatok szorosabbá válása következtében is megtöbbszöröződött az utazások száma, ennek folytán a multinacionális cégek százával utaztatnak szakembereket a sejkségbe, ahonnan hasonló gyakorisággal érkeznek tárgyalópartnerek Berlinbe. A mind gazdasági, mind kulturális téren egyik legsikeresebb tartományi főváros, Suttgart, valamint világhírü iparvállalati (Daimler A.G., Porsche, Bosch stb.) ugyancsak tarthatatlannak tartották azt a képtelen helyzetet, hogy jobb híján Frankfurton vagy Münchenen keresztül kénytelenek tartani a légi kapcsolatot Dubajjal [24].

Mindezeken túlmenően a német légitársaságok a szolgáltatási aránytalanságot ítélik elfogadhatatlannak, nevezetesen, hogy miközben ők az öböltérségbe hetente csupán 18 járatot, az öbölbeli társaságok Németországba már 91-et közlekedtethetnek [20]. 


\section{Légi közlekedés}

A Lufthansához hasonlóan az Air Canada is tiltakozott az ellen, hogy az Emirates akárcsak egyetlen járatával is benyomuljon Kanadába. Nem is kapott a kanadai kormánytól engedélyt arra, hogy hálózatába bevonja Calgarit és Vancouvert. Az Egyesült Államok legnagyobb légitársaságai (American Airlines, United Airlines és Delta) úgyszintén igyekeznek lobbizni a washingtoni kormánynál, hogy korlátozza az agresszív arab társaság jelenlétét a nemzetközi piacukon [23].

Dubaj sejkség nagy szerepet szán az Emiratesnek abban, hogy Dubaj váljon a világ legnagyobb légi közlekedési forditókorongjává, olyan átszállóhellyé, amely azon felül, hogy az Európa, Ázsia és Afrika közötti forgalmat közvetíti, Észak-, sőt Dél-Amerikával is kapcsolatot teremt közvetlen járataival. E cél megvalósulását számos adat, információ támasztja alá. Dubaj repülötér-komplexum ([15] megfogalmazásában a „super-connecting hub”) kivételes fordítókorong szerepét a globális légi közlekedésben a transzferutasok 50\%-ot jóval meghaladó arányához képest a hatalmas létszámuk (2015-ben 26 millió fö) még inkább aláhúzza.

A már több évtizedes múltra visszatekintő, szinte folyamatosan fejlesztett, és így már évi 90 millió utaskapacitással rendelkező Dubai International Airporton (DXB) és a 2020ban megrendezendő világkiállítás igényeit kiszolgáló, épülő Al Maktoum International Airport 2014-től már üzemelő részlegén 2015ben együttesen 78,5 millió, 2016-ban 85 millió utast kezeltek. Dubaj a nemzetközi légi forgalomban 2015-ben már világelső, a teljes forgalom tekintetében pedig a 3 . helyet foglalta el a világ top légikikötői közül. (Azonban a világvárosok teljes légi forgalmát tekintve még mindig London vezet - Heathrow, Gatwick, Stanstead és Luton együttes utasszáma alapján.) Teljes elkészülte után Maktoum forgalmi kapacitása évente 120-160 millió lesz [3].

Mivel az eddigi nemzetközi repülőtér megszünéséről nincs szó Maktoum átadása után, egészen példátlan méreteket ölthet Dubaj légi forgalma. Elméletileg az agglomerációs előnyök analógiájára alapozva a méret növeke- désével együtt kellene járjon a repülőtéri tevékenységek hatékonyságának javulása, azaz az economies of scale és a szinergia között pozitív korreláció feltételezhetö. Azonban a gyakorlat a jövőben nem biztos, hogy visszaigazolja a logikusnak tűnő percepciót. A légtér adott, nem bővíthető. A több futópályán való folyamatos és biztonságos le- és felszállások számának a legkorszerübb légi irányítás mellett is megvannak a müszaki, valamint követési távolsági, forgalomintenzitási korlátai és kockázatai.

A dubaji komplexum területi kiterjedése már ma is akkora, hogy az egymástól km-es távolságban levő terminálok közötti közlekedési és (az ehhez társuló) kezelési idő eleve határt szab a bruttó átszállási idő 40-45 perc alá csökkentésének. Ha viszont a legkisebb „homok kerül a gépezetbe”, pl. késik az a járat, amelynek utasai a csatlakozó járattal folytatnák útjukat, vagy néhány (már valahol a repülötéren levő) utas nem érkezik meg - pl. tájékozódási/kommunikációs hiba miatt - a csatlakozó gép indulásáig, akkor akár drasztikusan is módosítani kell több járat menetrendjét. („Pillangóeffektus”/dominóelv.) Azaz, ha a dubaji repülötér-komplexum méretei kezelhetetlenek lesznek, müködése rövidebb-hosszabb időre ellehetetlenedhet, „müszaki szaurusszá" válhat.

\section{ISZTAMBUL SEM MARADHAT LE}

A közel Németországnyi népességű Törökország és egyben Kelet-Európa legnagyobb metropolisza, Isztambul európai oldalán levő nemzetközi repülőtere (Atatürk Int. Airport) már ma is a legtekintélyesebb nyugat-európaiakkal összemérhető forgalmat könyvelhet el, és fordítókorong-szerepet tölt be egyfelől Délkelet-/Kelet-Európa, másfelől Közép-, Dél- és Kelet-Ázsia, továbbá Kelet-Afrika, valamint a Távol-Kelet és Afrika között [14]. A hazánk lakosságánál jóval népesebb metropolisz keleti elővárosában levő Sabiha Gökçen repülőtér a kiterjedt törökországi belföldi légihálózat origója, de kis- és középtávolságú nemzetközi járatokra is berendezkedett [10].

Isztambul a Kemál Atatürk köztársasága kikiáltásának 2023. évi centenáriumára nagy beruházásokkal, többek között az európai 
oldalon egy újabb, évi 160 millió utasra méretezett repülőtér építésével készül [19]. Ha az valóban megvalósul, akkor belátható időn belül a Közel-Keleten a nemzetközi légi közlekedés két giga-fordítókoronggal elősegitetten polarizálódhat és egyben globalizálódhat. Feltételezhető, hogy már csak a közel másfélezer km-es távolság és a szolgáltatási hálózatok, illetve a piacterületek gyengén részleges területi átfedése okán sem lesz kemény versenytársa egymásnak Dubaj és Isztambul, annál inkább lehet hasznos alkalmanként a kölcsönös kiegészítő, kisegítő fordítókorong-funkció [11].

\section{FELHASZNÁLT IRODALOM}

[1] Attwood, E. 2016: Emirates mocks Lufthansa CEO over 'blame games'. - http:// www.arabianbusiness.com/emiratesmocks-lufthansa-ceo-over-blamegames--620920.html\#.V6rYjfmLSUk

[2] Batchelor, D. 2014: Middle East hub airports winning long-haul passenger traffic race. - http://www.amadeus.com/ blog/16/04/middle-east-hub-airportswinning-long-haul-passenger-trafficrace/

[3] Capacity, Dubai Airport Review - http:// dubaiairportsreview.com/2013/ourresults/capacity/

[4] Cornwell, A. 2015: What next for Emirates? - http://gulfnews.com/business/aviation/what-next-for-emirates-1.1605961

[5] Dubai Economy Structure 2010 - http:// www.economywatch.com/world_ economy/dubai/structure-of-economy. html

[6] Erdősi F. 1998: Légi közlekedés általános és regionális földrajza, légiközlekedéspolitika. I. kötet. Budapest, Malév Rt.

[7] Erdősi F. 2003: A világ légi közlekedésének tendenciái. - Közlekedéstudományi Szemle, 2. p. 54-59.

[8] Erdősi F. 2015a: A hárompólusú KözelKelet közlekedése. - Kézirat. 650 p. MTA KRTK Regionális Kutatások Intézete, Pécs

[9] Erdősi F. 2015b: A Dubaj-szindróma. A Perzsa-öböl régiója mint a globális légi közlekedés új súlypontterülete és fordítókorongja. - Külügyi Szemle, 2. p. 78-95.

[10] Erdősi F. 2015c: Törökország közlekedé- se. Pécs, MTA KRTK Regionális Kutatások Intézete. $430 \mathrm{p}$.

[11] Erdősi F. 2016: Verseny vagy együttmüködés? (A Közel-kelet hárompólusú légi közlekedésének kilátásai.) In: Tamás J. Popp J. (szerk.): Baranyi Béla 70. Kapocs. - Debrecen, Debreceni Egyetem Gazdálkodástudományi és Vidékfejlesztési Kar; Mezőgazdaság-, Élelmiszer $\neg$ tudományi és Környezetgazdálkodási Kar, pp. 124-131. https:/dea.lib.unideb.hu/dea/ handle/2437/228567

[12] Flug Revue 2008: Dubai airport plans big expansion drive. - www.flugrevue. de/index.php7id=2159

[13] Hvidt, M. 2009: The Dubai Model. International Journal of Middle East Studies, 1. p. 4-6.

[14] Istanbul Atatürk Airport - http:// en.wikipedia.org/wiki/Istanbul_Atatürk_Airport

[15] Kamel, D. 2016: Emirates Sales Decline Reveals Challenges to Mega-Carrier Model. - http://www.bloomberg.com/ news/articles/2016-05-10/emiratessales-decline-reveals-challenges-tomega-carrier-model

[16] Kindergan, A. 2014: Fluggeselschaften aus der Golfregion im Aufwind. https://www.credit-suisse.com/ch/de/ articles/news-and-expertise/2014/07/de/ the-rise-of-the-gulf-carriers.html

[17] Knibb, D. 2008: Emirates leads from the front. - Airline Business, 1. p. 20.

[18] Little, A. D. 2007: Kostenvorteile der Middle East Carrier. Eine Quantifizierung struktureller und strategischer Vorteile im Vergleich zu europäischen Netzwerk Carriern. - http://www.adlittle.de/uploads/tx extthoughtleadership/ADL_Aviation Studie_Middle_East_Carrier_2007. pdf

[19] MATPUM Master Plan Studies - kongre. nigde.edu.tr/mdek/dosyalar.pdf

[20] Murel, M. - O'Connell, J. F. 2011: Potential for Abu Dhabi, Doha and Dubai Airports to reach their traffic objectives. - Research in Transportation Business \& Management, 1. p. 36-46. DOI: https:// doi.org/10.1016/j.rtbm.2011.06.004 


\section{Légi közlekedés}

[21] Oxford Economies - Amadeus. Shaping the Future of Travel. Macro trends driving industry growth over the next decade. - http://www.amadeus.com/ documents/Thought-leadership-reports/ A madeus-Shaping-the-Future-ofTravel-MacroTrends-Report.pdf

[22] Rürup, B. - Reichart, T. 2014: Determinanten der Wettbewerbsfähigkeit im Internationalen Luftverkehr. - Handelsblatt Research Institute - https://www. bdl.aero/download/1209/

deter- minanten-der-wettbewerbsfahigkeitiminternationalen-luftverkehr.pdf

[23] Singhai, M. 2011: Emirates, Etihad \& Qatar Airways challenge global dominance of European \& American Airlines http://economictimes.indiatimes. com/articleshow/8932847. cms?utm source =contentofinterest \&utm medium $=$ text $\&$ utm_campaign $=$ cppst [24] Tearing down the other wall http://www.emirates.com/it/italian/ images/Tearing_down_to_ the_other_ wall_tcm262-579859.pdf

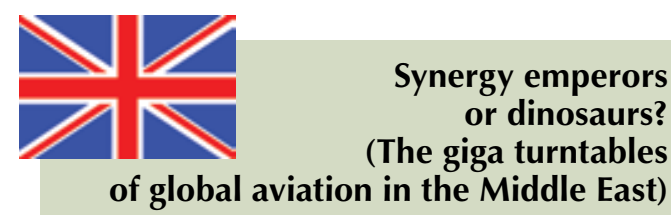

The Persian Gulf region due to its favourable logistical location between Europe and the Middle East, playing the role of intercontinental air traffic turntable - (longdistance air transport and maritime freight delivery) has changed from periphery into a new focal area of the global transport. The article highlights the importance of the interdependence between the transformation of the economic structure and aviation in the exceptionally rapidly developing region; furthermore it analyses the internal and external factors of the unprecedented growth of the Dubai aviation sector making it extremely compet-itive even on global level.

Another giga-hub complex of the Middle East is now shaping up in Istanbul, which is unlikely to be a real competitor to Dubai because of the large distance between them. However, the two giant nodes may play from time to time a mutually complementary/ subsidiary role.

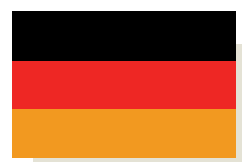

\section{KAISER DER SYNERGIEN} ODER SAURIER ? (Die Giga-Drehscheiben des globalen Luftverkehrs im Nahen Osten)

Der Raum des Persischen Golfes hat sich anhand seiner günstigen logistischen Lage, und durch ihre Einrichtung auf die Rolle des multikontinentalen "Drehscheibe" des Luftverkehrs von einer Peripherie zum Schwerpunkt des globalen Verkehrs (sowohl in der Luftverkehr als auch in dem Schiffstransport) umgewandelt. In dem Artikel es wird die Bedeutung der gegenseitigen Abhängigkeit des ökonomischen Strukturwandels und des Luftverkehrs hinsichtlich der aussergewöhnlichen Entwicklung des Wirtschaftsraumes. Es werden weiterhin die äusseren und inneren Einflussfaktoren für die beispiellose Entwicklung der Luftfahrtsektors von Dubai analysiert, wodurch hier eine auch global gesehen eine sehr starke Wettbewerbsfähigkeit erreicht wurde.

Der andere Giga-Hubkomplex entfaltet sich in Istambul, welche aber wegen der grossen Entfernung kaum eine wahre Konkurrenz für Dubai bedeuten wird. Gleichzeitig können aber diese beiden Knotenpunkte eine komplementäre/stellvertretende Rolle ausüben. 